THE KURUME MEDICAL JOURNAL

Vol. 28, p. 349-351, 1981

\title{
Benzodiazepines and the Gamma-aminobutyric Acid (GABA) Receptor
}

\author{
HIDEHO HIGASHI, HIROE INOKUCHI, SYOGORO NISHI \\ AND KAZUTOYO INANAGA* \\ Departments of Physiology and Neuropsychiatry*, Kurume University School \\ of Medicine, Kurume, 830 and Chikusuikai Institute for Neuroinformation, \\ Yame, 834 Japan
}

Received for publication December 24, 1981

\begin{abstract}
Key words: benzodiazepines - diazepam - chlordiazepoxide - GABA
receptor - primary afferent neurones - spinal ganglion
\end{abstract}

The site and mechanism of action of benzodiazepines on GABA-mediated transmission within the central nervous system (CNS) is a matter of controversy (Haefely et al. 1976; Steiner and Felix, 1976; Iversen, 1977). Benzodiazepines have been reported to facilitate presynaptic inhibition in the spinal cord as a result of augmentation of the GABA-mediated primary afferent depolarisation (Schmidt et al. 1967; Schlosser, 1971; Polc et al. 1974). Similarly, chlordiazepoxide has been shown to mimic GABA in decreasing the firing rate of neurones in the brain stem (Dray and Straughan, 1976) and the sensorimotor cortex (Kozhechkin and Ostrovskaya, 1977). On the contrary, benzodiazepines have been characterised to antagonise the inhibitory action of GABA on the neurones in the cerebellum (Steiner and Felix, 1976; Gahwiler, 1976). Precise interpretation of these indirect evidences is, however, difficult in view of the complexity of synaptic connections in CNS.

We therefore investigated the direct action of benzodiazepines on the GABA receptor of cat primary afferent neurones, which produces a chloride-dependent depolarisation in response to the agonist (Gallagher et al. 1978). These neurones are monopolar and devoid of synaptic inputs on their somata so that the drug action on the GABA receptor can be assessed without any extrinsic interactions. Our result showed that diazepam and chlordiazepoxide caused a depression, instead of a facilitation, of the GABA-induced depolarisation and that the kinetics of such an action of the drugs appeared to be non-competitive in nature.

Experiments were carried out on the L-7 or S-1 spinal ganglion which was excised from adult mongrel cats anaesthetised with alpha-chloralose. Intracellular recordings were made from the somata of ganglion neurones with the methods essentially similar to that of Gallagher et al (1978).

As seen in Fig. 1, diazepam depressed dose-dependently the amplitude of GABA depolarisation of primary afferent neurones. The action was fairly rapid in onset and completely reversible. The minimal effective concentration was $10^{-6} \mathrm{M}$. At $10^{-5}$ and $10^{-4} \mathrm{M}$ diazepam caused, in addition to the depression, a slight (7-15\%) prolongation of GABA depolarisation, while it was without effect on the resting membrane potential or resistance.

It was found from dose-response curves (Fig. 2) that diazepam lowered the maximum amplitude of GABA depolarisation without affecting the dissociation constant of the GABA-GABA receptor complex. A 


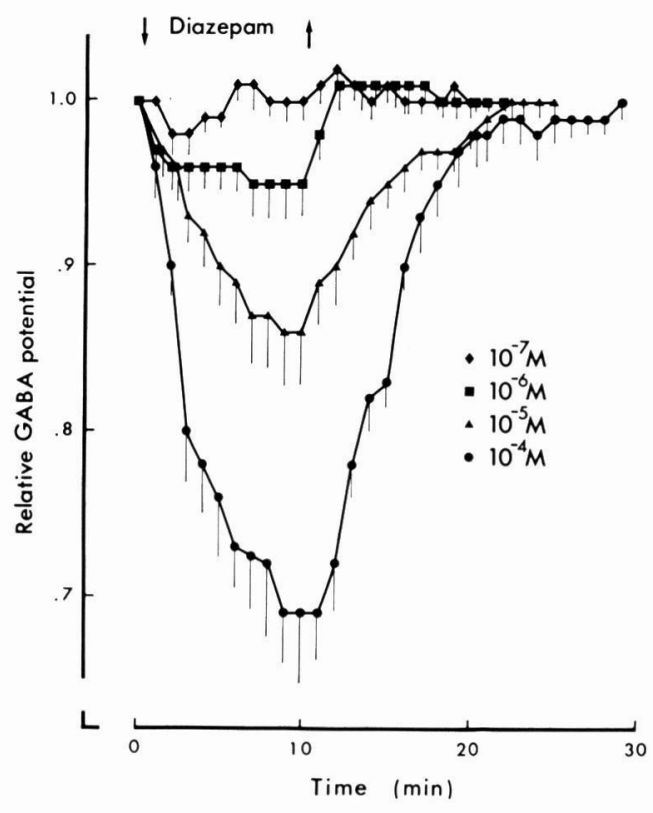

Fig. 1. Depression of GABA-induced depolarisation by diazepam. GABA was iontophoresed to the surface of a primary afferent neurone from a microelectrode filled with $1 \mathrm{M}$ GABA adjusted to $\mathrm{pH} 4.0$. Iontophoretic current pulses has a fixed intensity $\left(2 \times 10^{-8}\right.$ to $\left.5 \times 10^{-8} \mathrm{~A}\right)$ and duration $(50 \mathrm{msec})$. Potassium citrate $(2 \mathrm{M})$ microelectrodes with tip resistances of 20 to $40 \mathrm{M} \Omega$ were employed for intracellular recordings. Ordinate: amplitude of GABA-induced depolarisations expressed as a fraction of the mean amplitude of control recordings which was taken to be unity. Abscissa: time after the beginning of superfusion with a diazepam-containing Krebs solution. In each trial diazepam $\left(10^{-7}\right.$ to $\left.10^{-4} \mathrm{M}\right)$ was applied for $10 \mathrm{~min}$ as indicated by two arrows.

similar non-competitive depression of GA BA depolarisation was also seen during superfusion with chlordiazepoxide which at concentrations $10^{-5}$ and $10^{-4} \mathrm{M}$ decreased the amplitude of GABA depolarisation by $6.7 \pm 1.6 \%$ and $12.6 \pm 1.6 \%$ (s.e., $\mathrm{n}=12$ neurones), respectively. At the corresponding concentrations diazepam depressed GABA depolarisation by $14.2 \pm 3.1 \%$ and $30.8 \pm 4.3 \%$ (s. e., $\mathrm{n}=18$ neurones), respec-



Fig. 2. Effect of diazepam on GABA depolarisation vs. iontophoretic current relationship. All plots were obtained from the same neurone. Each arrow points the $\mathrm{K}_{\mathrm{m}}$ value; the dissociation constant of GABA-GABA receptor complex. Measurement of GABA depolarisation under the influence of diazepam was commenced $10 \mathrm{~min}$ after the beginning of drug application by which time the depression of GABA depolarisation by a given concentration of diazepam had reached its maximum.

tively (Fig. 1). Thus, diazepam appeared to be 2 to 3 times more effective than chlordiazepoxide in depressing the GABA potential. It is also evident from the doseresponse data that the depressant action of diazepam as well as chlordiazepoxide is exerted by their combination with an allosteric site but not the recognition site of GABA receptor.

Despite such a depressant action of diazepam and chlordiazepoxide on the GABA receptor, benzodiazepines, as mentioned above, facilitate presynaptic inhibition and augment the synaptically induced primary afferent depolarisation. This paradox re- 
flects that the site of facilitatory action of benzodiazepines is in the elements presynaptic to the primary afferent nerve terminals. It is likely that in in vivo conditions the facilitatory action of benzodiazepines on the GABA-ergic system overwhelms their depressant effect on the GABA receptor mediating presynaptic inhibition.

It should be added that both diazepam and chlordiazepoxide are much weaker depressants than picrotoxin and bicuculline, the well-known GABA antagonists which also noncompetitively depress the GABA receptor on the primary afferent neurones (Gallagher et al. 1978) with $\mathrm{ED}_{50}$ of approximately $10^{-6} \mathrm{M}$.

This study was supported in part by the Ministry of Education, Science and Culture of Japan.

\section{References}

Dray, A. and Stralghan, D. W. J. (1796). Benzodiazepines: GABA and glycine receptors on single neurons, in the rat medulla. J. Pharm. Pharmac. 28, 314-315.

GäHWILER, B.H. (1976). Diazepam and chlordiazepoxide: powerful GABA antagonists in explants of rat cerebellum. Brain Res. 107,
176-179

Gallagher, J. P., Higashi, H. and Nishi, S. (1978). Characterization and ionic basis of GABA induced depolarizations recorded in vitro from cat primary afferent neurones. J. Physiol. 275, 263-282.

Haefely, W., Pieri, L., Polc, P. and Schaffner, R. (1976). Benzodiazepines and GABA. Nature, 263, 173-174.

IVERSEN, L. (1977). Anti-anxiety receptors in the brain? Nature, 266, 678 .

Kozhechin, S. M. and Ostrovskaya, R. U. (1977). Are benzodiazepines GABA antagonists? Nature, 269, 72-73.

Polc, P., Möhler, H. and Haefely, W. (1974). The effect of diazepam on spinal cord activities: possible sites and mechanisms of action. Naunyn-Schmiєdebergs Arch. Phar: mak. 284, 319-337.

Schlosser, W. (1971). Action of diazepam on the spinal cord. Archs. int. Pharmacodyn. Ther. 194, 93-102.

Schmidt, R.F., Vogel, M.E. and Zimmerman, M. (1967). Die Wirkung von Diazepam auf die präsynaptishe Hemmung und andere Rükenmarksreflexe. Naunyn-Schmiedebergs Arch. Pharmak. 258, 69-82.

Steiner, F.A. and Felix, D. (1976). Antagonistic effect of GABA and benzodiazepines on vestibular and cerebellar neurones. $\mathrm{Na}$ ture, 260, 346-347.

Steiner, F. A. and Felix, D. (1976). Benzodiazepines and GABA. Nature, 263, 174. 